\title{
A CONVENÇÃO DE ARBITRAGEM NO COMÉRCIO EXTERIOR BRASILEIRO
}

\section{Diego Matos Marinho}

Tecnólogo em Comércio Exterior pelo Instituto Federal de Educação, Ciência e Tecnologia do Rio Grande do Norte. Bacharel em Direito pela Universidade Federal do Rio Grande do Norte. Advogado militante. Membro da Comissão de Relações Internacionais da Ordem dos Advogados do Brasil - Seccional Rio Grande do Norte.

E-mail: dimmarinho@gmail.com.

Ítalo Marcio Gurgel Castro

Bacharel em Direito pela Universidade Federal do Rio Grande do Norte. Professor do Curso de Tecnologia em Comércio Exterior do Rio Grande do Norte.

E-mail: italocastro@cefetrn.br

\section{RESUMO}

A presente monografia faz considerações acerca da Convenção de Arbitragem no âmbito do comércio exterior. Objetiva compreender os efeitos da Convenção de Arbitragem em torno dos negócios internacionais privados brasileiros, considerando a perspectiva desse instituto como opção às necessidades dos atores envolvidos nessa intensa atividade. $\mathrm{O}$ estudo foi feito por meio da interface entre informações obtidas através de pesquisas bibliográficas e websites, destacando-se o saber depreendido dos autores Nadia Araújo e He Moon Jô, e suas respectivas obras Direito Internacional Privado: Teoria e Prática Brasileira, e Introdução ao Direito Internacional. Importante citar também a contribuição de outros autores como Antônio Carlos Rodrigues do Amaral, Maurício Godinho Delgado, Selma Maria Ferreira Lemes e José Augusto da Silva, e suas respectivas obras: Direito do Comércio Internacional: aspectos fundamentais; Curso de Direito do Trabalho; A Arbitragem Doméstica e Arbitragem Internacional, e A Arbitragem no processo de Globalização. De posse de um aporte teórico e das informações obtidas, foi possível fazer um estudo qualitativo do conhecimento adquirido e observar o progresso e a influência da arbitragem internacional no que se refere aos negócios internacionais. Ante a pertinência do tema como modo alternativo de solução de conflitos, demonstra a imprescindibilidade jurídica e econômica do tema para o Comércio Exterior e para a política brasileira de incentivo ao comércio internacional, uma vez que desafoga o Poder Judiciário e confere maior segurança aos investidores e comerciantes.

PALAVRAS-CHAVE: Arbitragem, Comércio exterior - Brasil, Globalização - Conflitos

\section{ARBITRATION CONVENTIONS IN BRAZILIAN INTERNATIONAL TRADE}

\section{ABSTRACT}

The present research brings some notes about arbitration conventions in international trade. Its main objective is to comprehend the effect of arbitration conventions on private international business from Brazil, taking into account the perspective about this institute being an option to the needs of people who participate in such activity. The study was done throughout the interface between importation found by bibliographic and websites researches. Emphasizing the inferred knowledge of the authors Nadia Araujo and He Moon Jo, and their respective international private law masterpieces: Theory and Brazilian 
practice and introduction to international low. In possession of a theoric knowledge and observes the progress and the influence of the international business. The subject's revelancy as an alternative way to solve conflicts demonstrates its legal and economic indispensability to international trade and brazilian policy of international trade promotion, since it takes some attributions from the legal system and gives more assurance to investors and traders.

KEY-WORDS: Arbitration, International trade - Brazil, Globalization - Conflicts.

\section{A CONVENÇÃO DE ARBITRAGEM NO COMÉRCIO EXTERIOR BRASILEIRO}

\section{INTRODUÇÃO}

A temática da Arbitragem há muito vem sendo discutida no cenário internacional, uma vez que a atual conjuntura do mundo globalizado faz resultar em uma intensificação das relações humanas e negociais.

No tocante aos negócios internacionais, verifica-se que a cada dia inúmeras operações são transacionadas entre diversas empresas e entre empresas e estados-nações. Nesse sentido, assim como nas relações humanas, é possível que dúvidas, divergências e conflitos apareçam a partir da celebração, interpretação e ou execução de contratos.

Visando a solução de tais conflitos e o afastamento do desgaste emocional e financeiro a que as partes são submetidas no Poder Judiciário, em face de sua burocracia e morosidade, tem-se recorrido muitas vezes a Arbitragem.

A arbitragem gradativamente se consagra como mecanismo eficaz para a solução de controvérsias, tornando-se uma ferramenta indispensável para as empresas e seus negócios. Desse modo, a temática da Arbitragem está sendo alvo de constantes discussões, desde o momento em que passou a ser utilizada como mecanismo rápido e econômico de solução de controvérsias, reflexo de um contexto da liberalização e globalização do comércio.

No que diz respeito à política externa brasileira, verifica-se que este país direciona suas ações para a ampliação das relações com o exterior e consequiente conquista de novos mercados. Nesse sentido, é elevado e crescente o número de transações comerciais realizadas, o que justifica o especial interesse sobre o tema em foco, e sobre as regras e conseqüências a ele relacionadas no âmbito do Direito Comercial Internacional e do Comércio Internacional.

Diante do exposto, e com o fulcro de conhecer melhor a influência do instituto da arbitragem nos negócios internacionais, diante de um cenário globalizado, competitivo e dinâmico, a presente monografia, procura responder a seguinte pergunta: Qual a influência da Convenção de Arbitragem no Comércio Exterior Brasileiro, após a edição da Lei de Arbitragem - Lei no 9.307/96?

Fazendo uso do pensamento de Araujo (2003, p.429), "a arbitragem vem sendo utilizada em litígios comerciais, com a proliferação de instituições arbitrais ligadas a câmaras de comércio ou associações comerciais". Sendo assim, um estudo que trate dessa realidade tende, pois, a contribuir para uma percepção mais aguçada sobre a resolução de eventuais conflitos comerciais no âmbito internacional.

Para tanto, mister se faz compreender os efeitos da Convenção de Arbitragem em torno dos negócios internacionais privados brasileiros, considerando a perspectiva desse instituto como opção às necessidades dos atores envolvidos nessa intensa atividade; assim como também é imprescindível o saber acerca do conceito, a origem e a evolução da arbitragem; dos tipos de arbitragem e sua diferença em relação a outras figuras próximas; e, por fim, 
compreender a arbitragem internacional, percebendo a importância desta nas relações de regulação dos litígios comerciais.

A presente pesquisa se enquadra como descritivo-analítica, uma vez que descreve as características de um fenômeno, no caso, o instituto da arbitragem, e analisa as conseqüências do mesmo.

O Universo de Pesquisa se restringe ao Brasil, uma vez que o estudo das características do fenômeno em tela far-se-á à luz do ordenamento pátrio ${ }^{1}$. A amostra é a mesma do universo de pesquisa.

A coleta de dados será realizada por fontes secundárias, bibliográfica e documental (livros, revistas, jornais, artigos e websites).

\section{COMÉRCIO INTERNACIONAL}

O sistema de comércio exterior ganhou nova dimensão a partir do século XIX. Até então, aquele se caracterizava por ter como base as legislações de cada Estado, onde inexistia um sistema internacional de comércio, e a prática de comércio exterior era fortemente atrelada e dependente da cooperação dos principais países hegemônicos.

Todavia, esse cenário de sistema liberal entrou em xeque com o advento das duas guerras mundiais. Envolvidos pelas consequiências desses conflitos, notadamente pelo último, países como Estados Unidos e o Reino Unido se responsabilizaram pela mudança desse status quo e deram início a uma ordem econômica baseada no sistema internacional de livre comércio.

Em funcionamento até hoje, e tendo como referência a Conferência de Bretton-Woods ${ }^{2}$, esse sistema tem como embasamento filosófico a teoria da vantagem comparativa, desenvolvida por David Ricardo ${ }^{3}$ e John Stuart Mil, através da aplicação da teoria de Adam Smith ${ }^{4}$ às transações internacionais. Desta feita, a atual ordem econômica internacional prima pela liberalização do comércio internacional e pela divisão internacional do trabalho, resultando em benefícios a todos os países participantes.

Nessa ótica, percebe-se a liberalização do acesso ao mercado, a redução de barreiras ao comércio exterior e a liberalização da transação monetária. Em suma, pode-se falar em um mundo unificado por um mercado globalizado, tendo como lógica do sistema o aspecto econômico.

\footnotetext{
${ }^{1}$ Entende-se por ordenamento pátrio o conjunto de normas e leis que regem uma nação.

${ }^{2}$ A conferência de Bretton Woods abrangeu um conjunto de reuniões ocorridas em 1944, nas quais os líderes das principais nações capitalistas acordaram uma série de protocolos nas áreas comercial, cambial e financeira, com o intuito de conferir maior estabilidade às relações econômicas entre os países.

${ }^{3}$ David Ricardo ( 1772 - 1823 ) formulou com clareza o princípio básico de sua teoria do valor: o valor dos bens depende da quantidade de trabalho necessária a sua obtenção.

${ }^{4}$ Adam Smith, considerado o formulador da teoria econômica, foi o primeiro a lançar os fundamentos para o campo desta ciência. Ele tornou o assunto compreensível e sistemático e seu livro A Riqueza das Nações pode ser considerado como a origem do estudo da Economia. Ele defendeu que uma divisão apropriada da mão-de-obra pela sociedade, com cada pessoa se especializando naquilo que sabe fazer melhor, seria a melhor maneira de aumentar a produtividade e a riqueza de uma nação.
} 
Diante de tal globalização, tem-se como resultado a formação de vários blocos econômicos, em que atuam parceiros multilaterais (Estados e Empresas), e conseqüentemente, uma exacerbada prática de comércio internacional.

\section{CONTRATOS INTERNACIONAIS E DIREITO INTERNACIONAL}

As relações internacionais econômicas, na seara do comércio exterior, se instrumentalizam notadamente através dos contratos internacionais.

Conforme anota Moon Jo (2004, p.493), "o conjunto das normas legais que regem as relações econômicas internacionais geralmente é chamado de 'direito internacional econômico"'. Contudo, em consonância com o entendimento do supracitado autor, em que este se apóia na idéia de John H. Jackson e Luis Henkin, essa disciplina aborda principalmente as atividades econômicas, comerciais e empresariais dos governos e das empresas transnacionais, desde que presentes características transfronteiriças; excetuandose as concernentes às relações privadas.

Quanto às relações comerciais entre partes privadas, as mesmas são tratadas pelo Direito Internacional Comercial. Isso por que os contratos internacionais integram a parte especial do Direito Internacional Privado.

Saber qual a norma de Direito Internacional é aplicável a determinado caso, é ter ciência de que, segundo entendimento de Araujo (2003, p. 311), “o aplicador da lei seguirá a norma de Direito Internacional Privado como se fora uma seta indicativa do direito aplicável, e das normas jurídicas que regulam o caso sub judice".

Anteriormente, muito se utilizava como critérios para determinação da aplicação da lei, aquela do local da celebração do contrato (lex loci celebrationis), e a do local da execução (lex loci executionis). Os primeiros, nos países de direito civil, e os segundos, nos países da common law ${ }^{5}$. Já no século XX, tais critérios foram substituídos por outros mais flexíveis.

A presença em um contrato de um elemento que o faça referência a dois ou mais ordenamentos jurídicos, caracteriza a internacionalidade daquele. Nesse caso, é cabível às partes prever situações futuras e determinar regras de direito substantivo no âmbito contratual, afim de que essas situações sejam resolvidas; além de ser possível determinar

\footnotetext{
${ }^{5}$ Termo utilizado para referir-se a normas e regras de caráter jurídico não escritas, porém sancionadas pelo costume ou pela jurisprudência. $\mathrm{O}$ nome vem da concepção do direito medieval inglês que, ao ser ministrado pelos tribunais do reino, refletia os costumes comuns dos que nele viviam. Este sistema legal vigora na Inglaterra e em todos os países originalmente colonizados pelos ingleses. Parte do princípio de que as questões devem ser resolvidas tomando-se como base sentenças judiciais anteriores, e não preceitos legais fixados antecipadamente. Este princípio é o que o distingue do sistema do direito continental europeu e dos demais países. A reunião de sentenças judiciais sobre várias situações semelhantes permite extrair regras gerais que geram precedentes e que se convertem em orientações para o julgamento futuro dos juízes, em casos análogos.
} 
onde e como o litígio resultante será julgado, através da proposição de cláusulas de eleição de foro e de arbitragem.

Com isso, observa-se uma tendência no caminho de permitir às partes liberdade na escolha da lei aplicável. E sendo assim, o princípio da autonomia da vontade na determinação do direito aplicável passa a ser um dos pontos mais importantes dos certames internacionais. Tal teoria tem sido aceita mundialmente, embora as regras consubstanciadas pela escola italiana para definição da regra de conexão aplicável aos contratos internacionais (lei do local da celebração) ainda tenha grande utilização nos países de tradição romanogermânica da América Latina.

No caso do Brasil, o artigo $9^{\circ}$ da Lei de Introdução ao Código Civil (LICC) adota o critério da lei do local da celebração, a saber:

Art. $9^{\circ}$ Para qualificar e reger as obrigações, aplicar-se-á a lei do país em que se constituírem.

$\S 1^{\circ}$ Destinando-se a obrigação a ser executada no Brasil e dependendo de forma essencial, será ela observada, admitidas as peculiaridades da lei estrangeira quanto aos requisitos extrínsecos do ato.

$\S 2^{\circ}$ A obrigação resultante do contrato reputa-se constituída no lugar em que residir o proponente.

Não obstante a isso, o principio da autonomia da vontade encontrou respaldo na Lei 9.307/96, denominada Lei de Arbitragem, consoante o seu art. $2^{\circ}$ :

Art. $2^{\circ} \mathrm{A}$ arbitragem poderá ser de direito ou de eqüidade, a critério das partes.

$\S 1^{\circ}$ Poderão as partes escolher, livremente, as regras de direito que serão aplicadas na arbitragem, desde que não haja violação aos bons costumes e à ordem pública.

$\S 2^{\circ}$ Poderão, também, as partes convencionar que a arbitragem se realiza com base nos princípios gerais de direito, nos usos e costumes e nas regras internacionais de comércio.

\section{ARBITRAGEM: CONCEITO, ORIGEM E EVOLUÇÃO}

O mundo ocidental contemporâneo conhece distintos métodos de solução de conflitos. Dentre os grandes grupos em que se classificam tais métodos, encontra-se a heterocomposição.

Verifica-se nessa modalidade a intervenção de um agente exterior aos sujeitos originais que buscam a solução do conflito, transferindo àquele a dinâmica de solução da controvérsia.

Afirma Delgado (2005, p.1444) que na heterocomposição: 
em vez de isoladamente ajustarem a solução de sua controvérsia, as partes submetem a terceiro seu conflito, em busca de solução a ser por ele firmada ou, pelo menos, por ele instigada ou favorecida.

Dentre as modalidades de heterocomposição, tem-se a arbitragem.

A arbitragem é um meio de solução de litígios que ocorre quando a solução destes é entregue a um terceiro, denominado árbitro, e, em geral, escolhido pelas próprias partes.

Quando utilizada a arbitragem, o resultado da resolução do conflito consuma-se através do laudo arbitral, que nada mais é que o ato através do qual o árbitro decide o litígio trazido a seu exame.

Desse modo, Arbitragem é o tipo procedimental de solução de conflitos mediante o qual a decisão, lançada em um laudo arbitral, efetiva-se por um terceiro, árbitro, estranho à relação entre os sujeitos em controvérsia e, em geral, por eles escolhidos.

No Brasil, a arbitragem é conhecida desde a época do Império. Para algumas matérias indicadas no Código Comercial de 1850 tinha caráter obrigatório.

Com o advento do Código de Processo Civil (CPC) de 1939, e posteriormente, sem grandes alterações, no de 1973, previu-se o juízo arbitral, de alcance uniforme para todo o Brasil. Em 1996 foi editada a lei específica para regular a arbitragem (Lei 9.307/96).

Antes da edição da referida lei, a arbitragem era desprovida de credibilidade como mecanismo alternativo de solução de conflitos, resultando na sua pouca utilização, devido ao fato da ausência de eficácia executiva da cláusula compromissória e da dificuldade de satisfazer todos os requisitos do compromisso arbitral, previsto no Código de Processo Civil.

No âmbito internacional, a sua pouca utilização justificava-se pela necessidade, para o reconhecimento e execução de sentenças arbitrais estrangeiras, de chancela no país de origem, previamente à sua homologação pelo Supremo Tribunal Federal (STF), evidenciando um duplo procedimento.

Com a lei de arbitragem, uma nova situação surge. Conforme assinala Araujo (2003, p.416), "entre outras inovações favoráveis à utilização da arbitragem, equiparou a cláusula compromissória ao compromisso, que são agora denominados, genericamente, convenção de arbitragem".

A sentença arbitral passa a ter força obrigatória, sendo dotada dos mesmos efeitos da sentença proferida pelo Poder Judiciário, e qualificando-a como título executivo extrajudicial, independente de qualquer homologação por parte daquele poder.

O princípio da autonomia da vontade das partes, consoante já afirmado anteriormente, também é exaltado quando confere aos contratantes ampla liberdade de escolha das normas a serem aplicadas ao certame, no que tange ao procedimento e ao fundo da causa, assim como também ovaciona a eleição dirigida aos usos e costumes do comércio internacional. Fazendo-se uso do entendimento de Araújo, a lei de arbitragem brasileira "procurou 
modernizar o instituto da arbitragem, conciliando a reticência historicamente verificada contra a arbitragem no Brasil com a utilização de mecanismos eficazes de preservação e garantia do procedimento".

\section{TIPOS DE ARBITRAGEM}

O instituto jurídico da arbitragem pode ser classificado de acordo com vários critérios. Desse modo, pode-se falar em arbitragem nacional e internacional; arbitragem obrigatória e voluntária; arbitragem legal ou convencional; arbitragem de direito e de eqüidade.

Fala-se em arbitragem nacional quando a resolução do conflito se faz sem a participação de entes estrangeiros, ou envolvem sujeitos de um mesmo Estado e sociedade, limitando o poder do árbitro ás fronteiras do respectivo Estado.

É internacional quando envolve indivíduos de distintos Estados e sociedades, e os interesses ultrapassam os limites fronteiriços de determinado país. Seus árbitros detêm poderes que abrangem os diferentes territórios de aplicação do laudo arbitral. Geralmente ocorre diante de conflitos entre grupos econômicos ou outros sujeitos de relevância no mercado mundial.

A arbitragem obrigatória é aquela imposta aos sujeitos, independente da vontade dos mesmos. Conforme assinala Delgado (2005, p. 1449), sobre arbitragem obrigatória:

pode resultar de imposição legal ou de prévia imposição convencional, estipulada pelas mesmas partes. Neste último caso, a convenção fixadora de semelhante obrigatoriedade, constante de prévio contrato entre as partes, é denominada cláusula compromissória (art. 4º Lei n. 9.307, de 1996 - Lei de Arbitragem).

A arbitragem voluntária (ou facultativa) surge no momento do conflito por opção das partes. Nessa situação, a convenção que elege a arbitragem denomina-se compromisso arbitral.

Quanto à arbitragem legal, esta advém de norma heterogênea estatal. Vale salientar que a previsão normativa não implica, necessariamente, em obrigatoriedade, podendo as partes, em alguns casos, dispor ou não desse instituto.

A arbitragem resultante do ajuste das partes denomina-se convencional. Tal ajuste pode se dar antes do surgimento do conflito, tornando-se obrigatória, mediante a cláusula compromissória, ou ser determinada no momento da eclosão da controvérsia; nesse caso, mediante compromisso arbitral (Anexo I).

Quando o conflito tem por objeto a interpretação de regra ou princípio jurídicos ou de cláusula contratual, tem-se a arbitragem de direito.

Por sua vez, a arbitragem de eqüidade tem por objeto de conflito os interesses materiais ou circunstanciais, de caráter econômico, disputados pelas partes. 


\section{FIGURAS PRÓXIMAS DA ARBITRAGEM}

Existem algumas figuras próximas da arbitragem, mas que devem ser diferenciadas, a fim de se evitar eventuais equívocos. Neste pleito, pode-se citar o arbitramento, a perícia técnica, a mediação, a transação e a jurisdição.

O arbitramento não se confunde com a arbitragem, uma vez que aquele é simples modalidade de liquidação de sentença judicial, tipificada em lei, através da qual o juiz designa perito para fixação do respectivo quantum debeatur resultante da sentença liquidanda.

A perícia técnica é uma modalidade de prova, a qual quem a realiza é um profissional qualificado. Ao fim da diligência, a matéria objeto da perícia integrará o processo.

A mediação é uma técnica de auxílio à resolução de conflitos, através do qual determinado agente, considerado terceiro imparcial diante dos interesses em dissenso e das respectivas partes conflituosas executa a função de aproximá-las para um debate, e sugerindo um resultado final pacificatório. O mediador difere do árbitro, pois não assume poder decisório perante as partes.

Nesse contexto, importante fazer alusão à Cláusula Escalonada. Esta, quando inserida em um contrato, prevê como forma de solução de controvérsias a mediação ou conciliação, anteriores à arbitragem. Conforme afirma Lemes,

esta cláusula verifica-se com certa freqüência em contratos de longa duração e complexidade, tais como os contratos de grandes obras de engenharia, contratos denominados de chave na mão, contratos nas áreas de energia, gás e petróleo, em que o inadimplemento contratual reflete nas consecutivas subcontratações e as desavenças surgidas e não solucionadas em tempo razoável podem comprometer todo o empreendimento. Há informes que atestam que nestes contratos $90 \%$ dos conflitos são resolvidos por meio deste sistema, aliado, às vezes, a outros métodos extrajudiciários de solução de conflitos.

Ressalta-se que quando as partes, num contrato, estipulam as cláusulas escalonadas, fazemno imbuídas das melhores intenções, no sentido de preservar a manutenção de um bom relacionamento comercial.

A Lei de Arbitragem dispõe sobre a possibilidade de interação entre formas de solução de conflitos autocompositivas e heterocompositivas, segundo reza o artigo $21, \S 4^{\circ}$, in verbis:
Art. 21 (Omissis)
(...)
$\S 4^{\circ}$ Competirá ao árbitro ou ao tribunal arbitral, no início do procedimento, tentar a conciliação das partes, aplicando-se, no que couber, o artigo 28 desta lei. 
O artigo 28 da supracitada lei enuncia a possibilidade de homologação da sentença arbitral, por árbitro ou tribunal arbitral, quando as partes chegarem a acordo quanto ao litígio; a saber:

Art. 28. Se, no decurso da arbitragem, as partes chegarem a acordo quanto ao litígio, o árbitro ou tribunal arbitral poderá, a pedido das partes, declarar tal fato mediante sentença arbitral, que conterá o requisitos do artigo 26 desta Lei.

Ocorrendo a mediação ou conciliação, e posteriormente iniciar-se a arbitragem, verifica-se que o mediador ou conciliador, salvo disposição em contrário das partes, haja vista as habilidades pessoais e confiança que as partes nele depositam, não poderá assumir a posição de árbitro, mantendo-se a imparcialidade necessária para atuar no dissídio.

Quando exclusivamente as próprias partes realizam concessões recíprocas sobre aspectos duvidosos de seus interesses, pondo fim ao litígio sem a interferência de um agente externo, tem-se o que se denomina de transação.

A jurisdição é o poder-dever do Estado de dizer o Direito existente sobre determinada situação litigiosa, através de segmento específico, que é o poder Judiciário, materializado na figura dos juízes e tribunais. Desse modo, as diferenças em face da arbitragem são substanciais.

\section{A ARBITRAGEM INTERNACIONAL E A REGULAÇÃO DOS LITÍGIOS COMERCIAIS}

\section{ADMISSIBILIDADE DA ARBITRAGEM INTERNACIONAL}

A arbitragem somente pode ser invocada por aquelas pessoas capazes de celebrar contratos, e para questões que envolvam direitos patrimoniais disponíveis. Desta feita, consoante alude Araújo (2003, p. 416) sobre a admissibilidade da arbitragem: "são insuscetíveis de submissão à arbitragem as questões extrapatrimoniais ou as que envolvam direitos indisponíveis".

A Lei de Arbitragem prevê no seu art. $1^{\circ}$ o cabimento de tal instituto, a saber:

Art. $1^{\circ}$ As pessoas capazes de contratar poderão valer-se da arbitragem para dirimir litígios relativos a direitos patrimoniais disponíveis.

Reforçando tal entendimento, o art. 852 do Novo Código Civil regulou parcialmente o tema, sendo defeso o compromisso à solução de questões de estado, de direito pessoal de família e outras que não tenham caráter estritamente patrimonial. Assim reza o art. 852 do NCC, in verbis:

Art. 852. É vedado compromisso para solução de questões de estado, de direito pessoal de família e de outras que não tenha caráter estritamente patrimonial. 
A constante utilização no âmbito internacional da Lei de Arbitragem, manifestada através de seus laudos, funciona como paliativo de um direito com normas próprias adequada aos usos e costumes do comércio internacional.

Isso porque a referida lei não prevê um regime jurídico diferenciado para as arbitragens internacionais realizadas no Brasil, assim como não define os contornos da arbitragem internacional.

Todavia, nada obsta a realização da arbitragem internacional no Brasil. Diante da lacuna jurídica sobre as características da arbitragem internacional, aquela deve ser suprida por analogia, costumes e princípios gerais de direito, conforme disposto no artigo $4^{\circ}$ da LICC, a saber:

Art. $4^{\circ}$ Quando a lei for omissa, o juiz decidirá o caso de acordo com a analogia, os costumes e os princípios gerais de direito.

Relativo à admissibilidade, dúvida pairava sobre a constitucionalidade dos entes da Administração Pública inserirem, nos contratos que firmam, a cláusula arbitral. As opiniões dos doutrinadores divergiam, uma vez que a legislação vigente apresenta dispositivos que autorizam a Administração a firmar convenções arbitrais, sobretudo nos contratos internacionais.

Resolvendo o dilema, o STJ ${ }^{6}$, em sede de recurso, posicionou-se a favor da aplicação da arbitragem para contratos firmados com empresas públicas ou sociedades de economia mista. Tal fato repercutirá em processos envolvendo as Parcerias Público Privadas (PPPs), no tocante à prestação de serviços públicos.

A decisão foi tomada no julgamento da demanda entre a AES Uruguaiana e Companhia Estadual de Energia Elétrica (CEEE). Aquela fez um contrato de comercialização de energia com a CEEE, em 1998, que continha cláusula prevendo a arbitragem para a resolução de conflitos, sendo escolhido a Câmara Comercial Internacional (CCI) de Paris, a mais conhecida instituição de arbitragem do mundo. O problema começou, em 2001, quando a CEEE se negou a resolver questões do contrato pela arbitragem. A estatal alegava que, como é uma prestadora de serviço público, possuía a opção pela arbitragem e não a obrigação de levar todos os conflitos para os árbitros. A CEEE disse ainda que, como prestadora de serviço público, não poderia ficar sujeita a um "juízo privado internacional".

A tese da CEEE foi vitoriosa na primeira instância e no Tribunal de Justiça do Rio Grande do Sul. Ambos desobrigaram a empresa a decidir os seus problemas por meio da arbitragem. O TJ concedeu liminar à CEEE, determinando a suspensão de procedimento arbitral instaurado a pedido da AES Uruguaiana, sob pena de multa diária. Esta recorreu a STJ, e teve seu recurso provido.

\footnotetext{
${ }^{6}$ Mesmo entendimento apresentou a $7^{\text {a }}$ CÂMARA CÍVEL DO TRIBUNAL DE ALÇADA DO PARANÁ, no julgamento da Apelação Civil em que fora apelante, Companhia Paranaense de Gás - Compagás, e apelado, Consórcio Carioca-Passarelli.
} 
No que tange à sentença, vale frisar, inicialmente, que aquela proferida em arbitragem internacional realizada no Brasil considerar-se-á uma sentença nacional, independendo de homologação pelo $\mathrm{STJ}^{7}$. De outro modo, a sentença arbitral proferida no estrangeiro sujeitar-se-á à homologação por parte do STJ, a fim de adquirir força executiva no Brasil, como reza o artigo 34 da Lei de Arbitragem - LA, in verbis:

Art.34. A sentença arbitral estrangeira será reconhecida ou executada no Brasil de conformidade com os tratados internacionais com eficácia no ordenamento interno e, na sua ausência, estritamente de acordo com os termos desta lei.

Parágrafo único: Considera-se sentença arbitral estrangeira a que tenha sido proferida fora do Território Nacional.

\section{EFEITOS DA CONVENÇÃO DE ARBITRAGEM PERANTE O JUDICIÁRIO LOCAL}

Anteriormente somente o compromisso arbitral tinha a capacidade de afastar o Judiciário local da situação litigiosa. Contudo, a LA inovou ao equiparar a cláusula compromissória ao compromisso, sendo ambos considerados genericamente Convenção de Arbitragem. Assim está disposto no artigo $3^{\circ}$, in fine:

Art. 3. As partes interessadas podem submeter à solução de seus litígios ao juízo arbitral mediante convenção de arbitragem, assim entendida a cláusula compromissória e o compromisso arbitral.

Sendo assim, à cláusula arbitral também é estendido o efeito supracitado. Isto é, a cláusula compromissória tem o efeito negativo de possibilitar o réu de argüir a incompetência do Judiciário por meio da exceção de convenção de arbitragem; conforme previsto no artigo 267 do CPC:

Art. 267. Extingue-se o processo, sem julgamento de mérito:

(...)

VII - pela convenção de arbitragem.

Esse mesmo efeito também alcança as arbitragens internacionais, desde que a situação conflituosa se encaixe em uma das hipóteses de competência concorrente da Justiça brasileira.

Outrossim, é resguardado às partes o direito de recorrerem ao Judiciário, por via de ação sumária, a fim de obter sentença ordenando a constituição do compromisso arbitral, caso a parte adversa se recusa a integrar a lide.

Muito se suscitou acerca da análise dos efeitos da cláusula compromissória, que poderiam levar a uma suposta inconstitucionalidade, visto que tal incidência afasta a apreciação do conflito do controle jurisdicional. E como é sabido, da Constituição Federal emana a

${ }^{7}$ Em decorrência da Emenda Constitucional no ${ }^{\circ} .45$ de 2004, o STJ substituiu o STF nesta tarefa. 
garantia da universalidade da jurisdição do Poder Judiciário, previsto no art. 5 $\mathrm{XXXV}$, cujo teor é o seguinte:

\author{
Art. $5^{\circ}($ Omissis $)$ \\ (...) \\ XXXV - a lei não excluirá da apreciação do Poder Judiciário \\ lesão ou ameaça a direito \\ (...).
}

A Lei de Arbitragem conferiu à cláusula compromissória absoluto caráter obrigatório. Desse modo, um instrumento contratual assinado por livre manifestação de vontade das partes, e que contenha cláusula de compromisso arbitral, quando da superveniência de algum conflito relativo a direito patrimonial, obriga a parte interessada a socorrer-se somente pela via arbitral, evitando-se o judiciário.

Tal discussão relativa à força obrigatória da cláusula arbitrária, e sua possível inconstitucionalidade, foi analisada pelo $\mathrm{STF}^{8}$, em demanda envolvendo uma empresa brasileira que mantinha relacionamento comercial (Contrato de Comissão) com uma empresa suíça. Em virtude de conflitos decorrentes desse relacionamento comercial, as partes firmaram, no dia 09.01.95, compromisso para realização de arbitragem ad hoc em Barcelona, Espanha. Iniciou-se o procedimento arbitral e, quatro meses depois, no dia 08 de maio do mesmo ano, foi emitido laudo arbitral que condenou uma das partes a pagar US\$ $332.000,00$ de lucros cessantes; US\$ 700.000,00 por danos morais (prestígio comercial) e mais US\$200.000,00 a título de ressarcimento de despesas, valores esses acrescidos de juros anuais de 5,5\%, desde 01.01 .95 até a data do efetivo pagamento. Foi proposta, então, Ação de Homologação de Laudo Arbitral Estrangeiro, a fim de que o laudo arbitral estrangeiro fosse cumprido.

O Presidente do STF negou a homologação do laudo, sustentando basicamente que, conforme a Constituição Federal e o Regimento Interno do STF (RISTF), não havia à época, previsão legal para homologar laudos arbitrais estrangeiros, mas tão-somente sentenças estrangeiras. Exigiu que o laudo fosse primeiramente homologado pelo Poder Judiciário espanhol (chancelado na origem por autoridade judiciária) para, em seguida, ser homologado no Brasil (dupla homologação).

Interpôs-se agravo regimental contra essa decisão, visto que esse procedimento é desconhecido pelo ordenamento jurídico espanhol. Em 10.10.96, o Ministro Sepúlveda Pertence deu provimento ao agravo, mas, com base nos arts. 176 e 177 do RISTF, no final da decisão, manifestou sua interpretação quanto à inconstitucionalidade da Lei $\mathrm{n}^{\circ}$ 9.307/96, sustentando a inafastabilidade do controle jurisdicional. Para ele, a Constituição não permite obstar o acesso ao Judiciário de lide que uma das partes quisesse submeter-lhe, tampouco forçar a outra parte a trilhar a via alternativa da arbitragem (art $7^{\circ}$ da Lei $\mathrm{n}^{\circ}$ 9.307/96).

${ }^{8} \mathrm{O}$ entendimento foi firmado em Acórdão pelo STF no julgamento de recurso em processo de homologação de Sentença Estrangeira, e publicado no Diário Oficial de Justiça no dia 30 de abril de 2004 (SE-AgR 5206). 
O Ministério Público Federal, na pessoa do Procurador-Geral da República à época, Dr. Geraldo Brindeiro, emitiu majestoso parecer pela constitucionalidade da lei. O mesmo destacou que:

(...) o que o princípio da inafastabilidade do controle jurisdicional estabelece é que a lei não exclui da apreciação do Poder Judiciário lesão ou ameaça a Direito. Não estabelece que as partes interessadas não excluirão da apreciação judicial suas questões ou conflitos. Não determina que os interessados devem sempre levar ao Judiciário suas demandas. Se se admite como lícita a transação relativamente a direitos substanciais objeto da lide, não se pode considerar violência à Constituição abdicar do direito instrumental de ação através de cláusula compromissória. E, em se tratando de direitos patrimoniais disponíveis, não somente é lícito e constitucional, mas é também recomendável aos interessados - diante do acúmulo de processos e do formalismo excessivo que têm gerado a lentidão das demandas judiciais - abdicarem do direito ou do poder de ação e buscarem a composição do conflito por meio de sentença arbitral cujos efeitos sejam idênticos àquele das decisões prolatadas pelo Poder Judiciário.

Ao fim da sessão plenária, a constitucionalidade foi declarada, considerando o Tribunal, por maioria de votos, que a manifestação de vontade da parte na cláusula compromissória, quando da celebração do contrato, e a permissão legal dada ao juiz para que substitua a vontade da parte recalcitrante em firmar o compromisso arbitral - em ação judicial específica para essa finalidade, nos termos do art. $7^{\circ}$ da Lei ${ }^{\circ} 9.307 / 96$ — não ofendem o art. $5^{\circ}, \mathrm{XXXV}$, da Constituição Federal.

De fato, sendo a arbitragem uma opção, uma faculdade, advinda de cláusula pactuada mediante livre disposição de vontade, e tendo como objeto direitos que podem ser exercidos livremente pelo seu titular, não há razão de o Judiciário exigir que somente ele possa resolver conflitos sobre matéria objeto de arbitragem. Muitas vezes conflitos de interesses são solucionados por acordo entre as partes, dentro ou fora do Judiciário, não se verificando, nesses casos, a dicção do direito pelo Poder Judiciário. Acertadamente decidiu o STF.

Em outras palavras, da forma como disciplinado pela lei de arbitragem, prevista a cláusula compromissória num determinado certame, em ocorrendo qualquer dissenso a respeito do teor do mesmo, as partes não poderão recorrer-se do Poder Judiciário para solucioná-la, mas sim terão que se sujeitar à decisão a ser proferida pelo árbitro escolhido para solucionar o compromisso arbitral então surgido, sob pena, nos termos do artigo $6^{\circ}$ e $7^{\circ}$, uma sentença judiciária converter aquela cláusula compromissória num compromisso arbitral, cuja decisão, consoante disposto nos artigos 18 e 31 da referida lei, produzirá, entre as partes e seus sucessores, os mesmos efeitos da sentença proferida pelo judiciário.

Os Tribunais de Justiça exararam entendimentos idênticos, bem como diversos precedentes de primeira instância, pois os juízes, ao depararem com a alegação da existência de cláusula compromissória, consideram-se impedidos para analisar a demanda, remetendo as 
partes à arbitragem. Contudo, ainda que esporadicamente, esse entendimento encontre resistência, pois alguns magistrados negam eficácia à cláusula compromissória, declarando-se competentes para apreciar a matéria. Mas, certamente, quando estas questões chegarem às instâncias superiores serão revistas. Para dar respaldo ao afirmado, pode-se citar as seguintes jurisprudências:

ARBITRAGEM - Juízo arbitral - Cláusula compromissória Opção convencionada pelas partes contratantes para dirimir possível litígio oriundo de inadimplemento contratual Possibilidade de que o contratante, caso sobrevenha litígio, recorra ao Poder Judiciário para compelir o inadimplente ao cumprimento do avençado que atende o disposto no art. $5^{\circ}$, XXXV, da CF - Juiz estatal que, ao ser acionado para compelir a parte recalcitrante a assinar o compromisso, não decidirá sem antes verificar se a demanda que se concretizou estava ou não abrangida pela renúncia declarada na cláusula compromissória - Interpretação dos arts. $4^{\circ}, 6^{\circ}$, par. ún., e $7^{\circ}$ da Lei 9.307/96. (STF; RT 777/189);

AÇÃO - Condições - Instituição de juízo arbitral - Alegação de falta de legítimo interesse processual - Acolhimento Existência de compromisso e procedimento arbitral validamente instalado perante órgão arbitral institucional livremente eleito pelas partes - Desnecessidade de intervenção judicial - Lei n. 9307/96 - Preliminar acolhida. (Agravo de Instrumento n. 124.217-4 - São Paulo - $5^{\text {a }}$ Câmara de Direito Privado - Relator: Rodrigues de Carvalho - 16.09.00 - V.U.);

EXTINÇÃO DO PROCESSO - Compromisso arbitral Partes que instituem que as controvérsias decorrentes do contrato seriam dirimidas por arbitragem - Impossibilidade jurídica do pedido - Impedimento de acesso ao Judiciário Inteligência da Lei no 9.307/96 (arbitragem) e artigo 267, inciso VII, do Código de Processo Civil - Obrigação de seguir a via escolhida - Recurso provido (Agravo de Instrumento n. 7.064.634-7 - São Paulo - 19a Câmara de Direito Privado - Relator: Sebastião Alves Junqueira 06.06 .06 - V.U. - Voto n.11.751) qsg07/96 - Preliminar acolhida. (Agravo de Instrumento n. 124.217-4 - São Paulo $5^{\text {a }}$ Câmara de Direito Privado - Relator: Rodrigues de Carvalho - 16.09.00 - V.U.);

ARBITRAGEM - Juízo arbitral - Execução - Contrato de exportação - Alegação, pela parte contrária, da existência de cláusula compromissória ou compromisso arbitral Impossibilidade do julgamento e processamento do feito pelo juízo comum - Extinção do processo sem julgamento do mérito - Inteligência dos arts. $4^{\circ}$ e $9^{\circ}$ da Lei 9.307/96, c/c os arts. 267, VII, e 301, IX, do CPC. (TAMG; RT 759/125). 
Importante salientar, conforme previsto no art. $8^{\circ}$ da LA, que eventual nulidade de quaisquer das cláusulas do contrato não afeta necessariamente a cláusula compromissória, visto que esta é independente. Ademais, em relação a esse tema, deve-se ressaltar ainda o princípio da competência, que autoriza o árbitro a decidir de ofício questões a respeito da existência, validade e eficácia da convenção de arbitragem e do contrato em que há uma cláusula compromissória, de acordo com o parágrafo único do citado artigo. A saber, a íntegra da previsão legal:

Art. $8^{\circ}$ A cláusula compromissória é autônoma em relação ao contrato em que estiver inserta, de tal sorte que a nulidade deste não implica, necessariamente, a nulidade da cláusula compromissória.

Parágrafo único. Caberá ao árbitro decidir de ofício, ou por provocação das partes, as questões acerca da existência, validade e eficácia da convenção de arbitragem e do contrato que contenha a cláusula compromissória..

\section{O LAUDO ARBITRAL INTERNACIONAL}

A sentença arbitral internacional, materializada no laudo arbitral, quando proferida no estrangeiro, obedecerá às leis do local o qual foi declarada.

Ao ser levado ao STJ, com vistas a ser homologada, as peculiaridades da sentença serão respeitadas, desde que, é óbvio, não sejam contrárias à ordem pública.

Assim dispõe o art. 39, I e II, da LA, in verbis:

Art. 39. Também será denegada a homologação para o reconhecimento ou execução da sentença arbitral estrangeira, se o Superior Tribunal de Justiça constatar que:

I - segundo a lei brasileira, o objeto do litígio não é suscetível de ser resolvido por arbitragem;

II - a decisão ofender a ordem pública.

Desta feita, a ausência de motivação da sentença, por exemplo, mesmo que permitida pela lei local onde foi julgado o dissenso, pode resultar na obstaculização do reconhecimento perante o STJ, se este se convencer que tal feito atenta à ordem pública, visto que no Brasil há a garantia da motivação da sentença, como sendo um dos direitos fundamentais abraçados pela Constituição.

Importante salientar que a rejeição por parte do pretório excelso dependerá da análise do caso concreto.

Pode-se citar as seguintes jurisprudências, as quais homologam sentenças arbitrais estrangeiras: 
HOMOLOGAÇÃO DE SENTENÇA ESTRANGEIRA. SENTENÇA ARBITRAL. MATÉRIA DE MÉRITO. IRRELEVÂNCIA. ART. 38 DA LEI N. 9.307/96.1. As disposições contidas no art. 38 da Lei n. 9.307/96 apresentam um campo mais largo das situações jurídicas que podem ser apresentadas na contestação, em relação à prevista no art. 221 do RISTF, mas não chega ao ponto de permitir a invasão da esfera de mérito da sentença homologanda. 2. A existência de ação anulatória da sentença arbitral estrangeira em trâmite nos tribunais pátrios não constitui impedimento à homologação da sentença alienígena, não havendo ferimento à soberania nacional, hipótese que exigiria a existência de decisão pátria relativa às mesmas questões resolvidas pelo Juízo arbitral. A Lei n. 9.307/96, no $\S 2^{\circ}$ do seu art.33, estabelece que a sentença que julgar procedente o pedido de anulação determinará que o árbitro ou tribunal profira novo laudo, o que significa ser defeso ao julgador proferir sentença substitutiva à emanada do Juízo arbitral. Daí a inexistência de decisões conflitantes. 3. Sentença arbitral estrangeira homologada. (STJ SEC 611 / EX 2005/0055688$0)$;

1. HOMOLOGAÇÃO DE SENTENÇA ESTRANGEIRA. LAUDO ARBITRAL QUE RECEBE "EXEQUATUR" DO TRIBUNAL DE GRANDE INSTÂNCIA DE PARIS. CITAÇÃO POR CARTA ROGATÓRIA DE EMPRESA SEDIADA NO BRASIL. 2. A SENTENÇA ARBITRAL ADQUIRE A AUTORIDADE DE COISA JULGADA QUANDO RECEBE O "EXEQUATUR", NÃO IMPUGNADO MEDIANTE APELAÇÃO. 3. HOMOLOGAÇÃO DE SENTENÇA ESTRANGEIRA JULGADA PROCEDENTE. (STF SE 3236. DJ 22-061984);

SENTENÇA ARBITRAL ESTRANGEIRA. PEDIDO DE HOMOLOGAÇÃO. CONTRATO DE AFRETAMENTO. REQUISITOS PREVISTOS NO REGIMENTO INTERNO DO STF E NA LEI No 9.307/96 (LEI DA ARBITRAGEM). Tendo as normas de natureza processual da Lei $\mathrm{n}^{\circ}$ 9.307/96 eficácia imediata, devem ser observados os pressupostos nela previstos para homologação de sentença arbitral estrangeira, independentemente da data de início do respectivo processo perante o juízo arbitral. Pedido que cumpre os requisitos dos arts. 37 a 39 da mencionada lei, bem como os dos arts. 216 e 217 do RI/STF. Homologação deferida. ( STF SEC 5828. DJ 23-02-2001).

Em contrapartida, pode-se citar jurisprudências, nas quais foi indeferido o pedido de homologação, por razões a saber: 
Arbitragem - Submissão da parte domiciliada no Brasil ao juízo arbitral no exterior - Admissibilidade, se a causa não versar sobre as hipóteses previstas no art. 89 do CPC Competência concorrente dos juízos brasileiro e estrangeiro. Abitragem - Laudo arbitral proferido antes da vigência da Lei 9.307/96 - Circunstância que não impede a aplicação da Lei de Arbitragem, pois, devido ao seu caráter nitidamente processual, tem incidência em todos os casos pendentes de julgamento. Arbitragem - Juízo arbitral Sentença estrangeira - Homologação - Citação Comparecimento à Câmara de Arbitragem de suposto representante da parte desprovido de procuração Inadmissibilidade - Inocorrência do ato citatório, que, independentemente da Lei 9.307/96, ofende aos princípios da ampla defesa e do contraditório, ensejando o indeferimento da homologação - Inteligência do art. 217, II, do RISTF. (STF SEC 5378);

SENTENÇA ARBITRAL ESTRANGEIRA. CONVENÇÃO DE ARBITRAGEM. INEXISTÊNCIA. COMPETÊNCIA NÃO DEMONSTRADA. HOMOLOGAÇÃO. IMPOSSIBILIDADE. 1. O requerimento de homologação de sentença arbitral estrangeira deve ser instruído com a convenção de arbitragem, sem a qual não se pode aferir a competência do juízo prolator da decisão (Lei 9.307, artigos 37, II, e 39, II; RISTF, artigo 217, I). 2. Contrato de compra e venda não assinado pela parte compradora e cujos termos não induzem a conclusão de que houve pactuação de cláusula compromissória, ausentes, ainda, quaisquer outros documentos escritos nesse sentido. Falta de prova quanto à manifesta declaração autônoma de vontade da requerida de renunciar à jurisdição estatal em favor da particular. 3. Não demonstrada a competência do juízo que proferiu a sentença estrangeira, resta inviabilizada sua homologação pelo Supremo Tribunal Federal. Pedido indeferido. (STF SEC 6753. DJ 04-10-2002);

HOMOLOGAÇÃO DE SENTENÇA ARBITRAL ESTRANGEIRA. CAUÇÃO: DESNECESSIDADE. COMPETÊNCIA DO JUIZ ESTRANGEIRO. APLICABILIDADE DA LEI No 9.307/96. INEXISTÊNCIA DE OUTORGA DE PROCURAÇÃO AO REPRESENTANTE DA REQUERIDA. CITAÇÃO NÃO COMPROVADA. PREJUDICIALIDADE DE OUTRAS QUESTÕES EM VIRTUDE DA FALTA DE REPRESENTAÇÃO. POSSIBILIDADE DE RENOVAR-SE O PEDIDO. 1. Não se exige caução em tema de homologação de sentença estrangeira (SEC no 3.407, Oscar Corrêa, DJ de 07.12.84). 2. Não se tratando da hipótese prevista no artigo 89 do CPC, a jurisprudência do STF tem 
admitido a competência concorrente dos juízos brasileiro e estrangeiro para julgamento de causa em que é parte pessoa domiciliada no Brasil. 3. A Lei $\mathrm{n}^{\circ}$ 9.307/96, dado seu conteúdo processual, tem incidência imediata nos casos pendentes de julgamento. 4. Não supre a citação o comparecimento à Câmara de Arbitragem de suposto representante da requerida desprovido de procuração. 5. Comprovada a ilegitimidade da representação, fica prejudicado qualquer exame sobre questões vinculadas ao contrato. 6. Hipótese em que, cumpridos os requisitos, poderá o pleito ser repetido. Pedido de homologação indeferido. (SEC 5378. DJ 25-02-2000).

É possível à parte interessada, mediante notificação à outra parte, solicitar, ao árbitro ou ao tribunal arbitral, pedido de correção material ou esclarecimento da sentença arbitral, segundo reza o art. 30 da LA:

Art. 30. No prazo de cinco dias, a contar do recebimento da notificação ou da ciência pessoal da sentença, a parte interessada, mediante comunicação à outra parte, poderá solicitar ao árbitro ou ao tribunal arbitral que:

I - corrija qualquer erro material da sentença arbitral;

II - Esclareça alguma obscuridade, dúvida ou contradição da sentença arbitral, ou se pronuncie sobre ponto omitido a respeito do qual devia manifestar a decisão.

(...).

Além disso, a decisão arbitral pode ser alvo ainda de uma ação anulatória ou rescisória e de embargos à execução por título extrajudicial. Sendo o laudo arbitral equiparado a sentença e podendo ser executado diretamente, uma vez que se trata de um título executivo extrajudicial, é possível que o devedor oponha àquela embargos de execução regulados no CPC durante o curso da ação de execução, dentro do prazo de 15 (quinze) dias, contados da juntada aos autos do mandado de citação; consoante dispõe os artigos 736 e 738, caput, do Código de Processo Civil, a saber in literis:

Art. 736. O executado, independentemente de penhora, depósito ou caução, poderá opor-se à execução por meio de embargos.

Parágrafo único. Os embargos à execução serão distribuídos por dependência, autuados em apartado, e instruídos com cópias (art. 544, $\S 1^{\circ}$, in fine) das peças processuais relevantes.

Art. 738. Os embargos serão oferecidos no prazo de 15 (quinze) dias, contados da data da juntada aos autos do mandado de citação. 
Quanto à ação anulatória ou rescisória, a parte interessada poderá recorrer ao Poder Judiciário competente a fim de obter a nulidade da sentença. Assim está previsto no art. 33, caput, da Lei de Arbitragem:

Art.33. A parte interessada poderá pleitear ao órgão do Poder Judiciário competente a decretação de nulidade da sentença arbitral nos casos previstos nesta Lei.

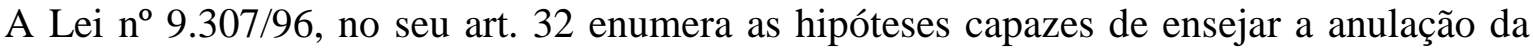
sentença arbitral, a saber:

Art. 32. É nula a sentença arbitral se:

I - for nulo o compromisso;

II - emanou de quem não podia ser árbitro;

III - não contiver os requisitos do art. 26. desta Lei;

IV - for proferida fora dos limites da convenção de arbitragem;

$\mathrm{V}$ - não decidir todo o litígio submetido à arbitragem;

VI - comprovado que foi proferida por prevaricação, concussão ou corrupção passiva;

VII - proferida fora do prazo, respeitado o disposto no art. 12, inciso III, desta Lei;

VIII - forem desrespeitados os princípios de que trata o art. $21, \S 2^{\circ}$, desta Lei.

No que tange a possibilidade de recurso à decisão arbitral, verifica-se que a Lei de Arbitragem é omissa neste ponto, conferindo às partes a liberdade de estipularem ou não tal expediente. Nesse sentido, tem-se a afirmação de Araujo (2004, p. 425):

Com relação à existência de uma segunda instância em sede arbitral, esta só existe quando a instituição utilizada dispõe de um sistema de revisão de mérito da causa, ou quando as partes convencionaram, numa arbitragem ad hoc, um sistema de revisão da sentença. A Lei de Arbitragem brasileira não preveniu tal situação, deixando-a a cargo das partes, de acordo com sua própria conveniência.

\section{ARBITRAGEM COMERCIAL INTERNACIONAL}

As controvérsias no mundo dos negócios envolvem cada vez mais aspectos técnicos de alta complexidade cujo equacionamento nem sempre se ajusta aos formalismos puramente processuais.

Somado a isso, mister se faz à solução de tais controvérsias, além da proficiência jurídica, substanciais conhecimentos especializados do mercado.

Outrossim, é o fato que o mercado almeja indefinidamente celeridade, tecnicidade e segurança. 
Nessa seara, a arbitragem se adequa perfeitamente, exaltando-se as qualidades supracitadas na sua mais pura essência. Desta feita, inúmeras empresas têm adotado cláusulas arbitrais nos mais variados tipos de contratos celebrados.

De fato, uma arbitragem reduz em muito o caráter de animosidade que notadamente marca as partes nos litígios forenses. Interessante, portanto, evitar-se o atrito e as sequielas próprias das intermináveis batalhas judiciais. Acrescente-se a tudo isto o sigilo e a confiança pessoal de cada parte no árbitro por ela escolhido.

Existe uma lei modelo que serviu de base para várias legislações internas no que se refere à arbitragem, inclusive para a brasileira. Fala-se da Lei Modelo da United Nations Commission on International Trade Law (da UNCITRAL) sobre arbitragem comercial internacional, e restrita apenas a esse tipo de atividade.

Em 24 de julho de 2002, foi publicado no Diário Oficial da União o Decreto Legislativo ${ }^{\circ}$. 4.311(Anexo II), que regulamenta a adesão do Brasil à Convenção de Nova York de 1958, também conhecida por Convenção da ONU sobre o Reconhecimento e Execução das Decisões Arbitrais Estrangeiras (Anexo III).

Considerada o acordo multilateral de maior importância no âmbito do Direito Arbitral Internacional, a Convenção de Nova York, que teve como base para sua existência a Lei Modelo da UNCITRAL, prevê, dentre outros pontos, o reconhecimento dos contratos por escrito de arbitragem internacional; a denegação quanto à permissão de uma disputa litigiosa entre as partes quando tal controvérsia deve estar sujeita à arbitragem, mediante contrato arbitral; e a homologação e execução das decisões arbitrais proferidas em território distinto daquele que se busca o reconhecimento e execução das mencionadas decisões.

No tocante ao reconhecimento da sentença arbitral, esta passa a ser obrigatório por cada Estado signatário, e sendo assim, o mesmo as executará de acordo com as regras procedimentais de dado território no qual a sentença for invocada; não incidindo outros procedimentos mais onerosos, taxas ou cobranças superiores àquelas.

A adesão do Brasil à Convenção de Nova York está contribuindo, indubitavelmente, para o avanço do Direito pátrio. Mais do que isso, tal movimento demonstrou a posição evolucionista do Brasil no âmbito nacional e internacional da arbitragem, na busca da facilitação e simplificação do reconhecimento e execução das decisões arbitrais proferidas em território distinto daquele que se busca o reconhecimento e execução de tais decisões, além de expandir o número de negócios internacionais.

Importante demonstrar desde já a existência de um outro meio de solução de solução de controvérsia aplicado no comércio internacional, o qual está presente a arbitragem em uma de suas etapas. Neste mecanismo de solução, controlada pela Organização Mundial do Comércio (OMC), apenas Estados podem fazer uso, diferentemente de um Tribunal arbitral, do qual podem fazer parte empresas privadas e Estados.

Nesse sistema, a solução de controvérsias inicia-se com as consultas prévias, passando-se então ao estabelecimento de um painel arbitral (através de notificação ao Órgão de Solução de Controvérsias). Da decisão arbitral cabe recurso ao Órgão de Apelação. Caso não haja 
espontâneo cumprimento da decisão arbitral, possibilita-se a adoção de medidas compensatórias em relação à parte vencida. Este último mecanismo garante a efetividade das decisões arbitrais

Ainda que o mecanismo de solução de controvérsias da OMC diferencia-se em alguns aspectos do procedimento arbitral ordinário, pode-se apontar algumas semelhanças entre ambos: independência e imparcialidade nas suas condutas e sigilo nas decisões.

Por outro lado, as diferenças verificadas são: maior participação das partes no mecanismo de solução de controvérsias da OMC; possibilidade de recorrer da decisão proferida por esta entidade e vedação à escolha dos julgadores (painelistas).

\section{PODER JUDICIÁRIO VERSUS ARBITRAGEM}

Consoante alusão feita por REZEK, a arbitragem é "uma via jurisdicional, porém nãojudiciária, de solução pacífica de litígios internacionais". Isso significa que o procedimento arbitral ocorre alheio ao judiciário.

A arbitragem internacional possibilita não apenas aos Estados mais também aos particulares sujeitarem suas demandas e conflitos a árbitros escolhidos de comum acordo pelas partes, evitando-se a sujeição destas a uma estrutura judiciária nacional.

Nesse sentido, a utilização da arbitragem confere vantagens que justificam a disseminação desse instituto, seja no âmbito nacional quanto no internacional.

Primeiramente, e de grande valia, tem-se a especialidade, ou seja, os árbitros podem ser técnicos. Muitas vezes a contenda submetida ao Judiciário incide sobre fatos extremamente técnicos e específicos que exigem a realização de perícia para que o juiz possa se inteirar e decidir sobre o assunto. $\mathrm{Na}$ arbitragem, geralmente, é o próprio especialista no assunto que avaliará e decidirá o dissídio.

A confidencialidade é outra vantagem do procedimento arbitral. Com frequiência, as partes em litígio desejam mantê-lo sob reserva, a fim de evitar o constrangimento e a exposição a terceiros, contribuindo assim para que não haja abalos em outras relações comerciais e nem se levante qualquer desconfiança infundada no mercado. Tal proteção dada às partes através do sigilo arbitral não existe quando da submissão da lide à análise do Judiciário.

No tocante à celeridade, verifica-se que o procedimento arbitral caracteriza-se por ser rápido, estando mesmo previsto, no momento de sua estipulação, o prazo máximo para solução de qualquer controvérsia futura. Diferentemente ocorre em relação ao Judiciário, o qual pode postergar uma lide por vários anos, o que pode resultar em prejuízo para as partes, em virtude principalmente da pletora de demandas e de recursos disponíveis.

Quanto aos custos, estes normalmente são menos dispendiosos na arbitragem do que nas longas e desgastantes lides judiciais. Todavia, é aconselhável realizar-se uma análise da relação custo-benefício do contrato a ser firmado quanto à inclusão da cláusula compromissória, em que se pesem a celeridade processual, a complexidade da matéria abordada e a possibilidade de sigilo, em comparação com a demanda judicial, 
considerando a morosidade do judiciário, uma vez que a arbitragem em uma controvérsia que verse sobre um valor pequeno nem sempre é interessante.

Vale salientar ainda que com o uso da arbitragem pelas empresas, é possível que haja uma otimização dos serviços prestados pelo Poder Judiciário, devido ao fato de um maior número de causas deixarem de ser apreciadas pela Justiça comum para serem solucionadas pelo meio alternativo da arbitragem.

\section{CONSIDERAÇÕES FINAIS}

A Arbitragem consiste num meio alternativo de solução de conflitos entre partes, mediante atuação de um árbitro, imparcial e, geralmente, escolhido por aquelas, e que tem poder decisório perante as mesmas, através de um laudo arbitral.

A Lei de Arbitragem representa um marco na história do Brasil, proporcionando uma transformação em importantes setores da vida nacional.

No aspecto sócio-econômico, a LA torna-se relevante, uma vez que busca manter as relações entre as partes, possibilitando-as continuar a atuar em conjunto nos contratos de longo prazo, assim como influencia a dinâmica do comércio exterior brasileiro.

A insegurança em relação aos efeitos da cláusula compromissória e as dificuldades decorrentes da necessária homologação das decisões arbitrais foram superadas pela edição da Lei $\mathrm{n}^{\circ}$ 9.307/96 e pela interpretação dada pela Corte Suprema. De fato, estes dois fatores configuravam como verdadeiros obstáculos ao bom desenvolvimento do aludido instituto no país, e, consequentemente, mitigavam o uso do mesmo nas práticas comerciais. Conferir caráter obrigatório à cláusula compromissória é dar certeza e segurança ao que foi combinado e acertado entre as partes quando do contrato. É dar garantia à arbitragem, que vem sendo uma alternativa interessante, diante de suas inúmeras vantagens e da descrença crescente dos cidadãos na intervenção do Poder Judiciário para resolver seus conflitos.

Não se pode deixar de mencionar a enorme contribuição dada ao instituto da arbitragem pelos Supremo Tribunal Federal e Superior Tribunal de Justiça. Afinal, o reconhecimento da constitucionalidade da LA pelo primeiro, e a conseqüente facilitação da homologação das sentenças arbitrais estrangeiras pelo segundo, confere maior credibilidade internacional, repercutindo na diminuição dos riscos, notadamente daqueles atinentes aos sistemas judicial e político brasileiros.

Desse modo, a consagração das normas de direito arbitral trazidas pela Lei $\mathrm{n}^{\circ}$. 9.307/96 faz com que haja uma ampliação dos negócios, visto que investidores e negociadores sentemse mais seguros e crédulos para realizar contratos financeiros e comerciais; sendo possível, em determinados casos, até a diminuição dos custos da transação.

Sendo assim, ao mesmo tempo em que a LA veio para se consagrar como importante instrumento de solução de conflitos, ao possibilitar que esta se revista de eficiência, justiça e ética, principalmente por permitir às partes a escolha de árbitros entre especialistas, sigilo no processo, celeridade e cooperação, veio também para contribuir com o aumento do comércio exterior brasileiro, uma vez que tal instituto diminui o risco das partes no âmbito 
das relações contratuais. Somado a isso, o Brasil passa a estar em maior sintonia com as nações que já fazem intenso uso da arbitragem, refletindo num melhor estreitamento das relações internacionais e, por conseguinte, negociais.

Desta feita, conclui-se que o instituto da arbitragem enquadra-se como um dos caminhos que possibilitará ao Brasil uma melhor preparação para as exigências e desafios da globalização, notadamente no que se refere ao dinamismo das atividades comerciais internacionais. Incentivar e propagar o uso de tal instituto significa ajustar-se ao contexto global das relações negociais, a ponto de elevar quantitativamente e qualitativamente o comércio internacional brasileiro.

\section{REFERÊNCIAS BIBLIOGRÁFICAS}

1. ALVES, André Camerlingo. A constitucionalidade da lei de arbitragem: Jurisprudência comentada. Disponível em: http://www2.oabsp.org.br/asp/esa/comunicacao/esa1.2.3.1.asp?id_noticias=42>. Acesso em: 6 jun. 07

2. AMARAL, Antonio Carlos Rodrigues do (coord.). Direito do comércio internacional: aspectos fundamentais. São Paulo: Aduaneiras, 2004.

3. AMARAL Jr. Alberto. Direito do comercio internacional. São Paulo: Juarez de Oliveira, 2002.

4. ARAUJO, Nadia de. Direito internacional privado: teoria e prática brasileira. Rio de Janeiro: Renovar, 2003.

5. BRASIL. Constituição (1988). Constituição da República Federativa do Brasil: promulgada em 5 de outubro de 1988. Organização do texto: Juarez de Oliveira. 4. ed. São Paulo: Saraiva, 1990. 168 p. (Série Legislação Brasileira).

6. BURATTO, Vicente Oliva. Arbitragem: o papel da arbitragem nas relações internacionais. Disponível em: <http://www.jurisnauta.com.br/modules/wfsection/article.php?articleid=715 >. Acesso em: 4 dez. 2006.

7. CASTRO, Róbison Gonçalves de. Relações econômicas internacionais. Brasília: Vest-con, 1998.

8. DELGADO, Mauricio Godinho. Curso de direito do trabalho. 4. ed. São Paulo: LTr, 2005.

9. FONTES, João Piza; AZEVEDO, Fábio Costa. A Lei da Arbitragem: análise à luz dos princípios gerais de direito . Jus Navigandi, Teresina, ano 4, n. 38, jan. 2000. Disponível em: <http://jus2.uol.com.br/doutrina/texto.asp?id=921>. Acesso em: 5 dez. 2006.

10. FREITAS, Fernanda Cristina Alem. Solução de conflitos: Arbitragem e a ratificação da convenção de Nova York. Disponível em: <http://conjur.estadao.com.br/static/text/8958,1>. Acesso em: 6 jun. 2007.

11. GLITZ, Frederico Eduardo Zenedin. A arbitragem internacional como sistema de solução privada de controvérsias. Disponível em: <http://jus2.uol.com.br/doutrina/texto.asp?id=3260>. Acesso em: 5 jul. 2007.

12. JO, He Moon. Introdução ao direito internacional. 2. ed. São Paulo: LTr, 2004. 
13. LEMES, Selma Maria Ferreira. A arbitragem doméstica e arbitragem internacional. Disponível em: <http://www2.oabsp.org.br/asp/esa/comunicacao/esa1.2.3.1.asp?id_noticias=83>. Acesso em: 5 dez. 2006

14.

A Jurisprudência brasileira sobre o uso da arbitragem. Disponível em: <http://www.institutodeengenharia.org.br/cmaie/informe_legislacao.php?l=1>. Acesso em 6 jun. 2007

15._ Cláusula escalonada mediação e arbitragem. Disponível em: <http://www2.oabsp.org.br/asp/esa/comunicacao/esa1.2.3.1.asp?id_noticias=84>. Acesso em: 6 jun. 2007

16. MAIA, Jayme de Mariz. Economia internacional e comércio exterior. 9. ed. São Paulo: Atlas, 2004.

17. MARTINS, Ives Gandra; WALD, Arnold. Lei de arbitragem: em 10 anos, lei deu eficiência e rapidez para os litígios. Disponível em <http://conjur.estadao.com.br/static/text/48599,1>. Acesso em: 6 jun. 2007.

18. PITOMBO, Eleonora Coelho. Arbitragem e contratos administrativos: caso COMPAGÁS. Disponível em: <http://www.cbsg.com.br/pdf_publicacoes/arbitragem_compagas.pdf.> Acesso em: 8 jun. 2007

19. REZEK, J. F. Direito internacional público. 2 ed.. São Paulo: Saraiva, 1991. p. 352

20. SANTOS, Rodrigo Ferreira; PIRES, Victor Paulo Kloeckner. Arbitragem internacional: uma análise à luz da legislação brasileira. Disponível em: $<$ http://www.mundojuridico.adv.br/sis_artigos/artigos.asp?codigo=562>. Acesso em 8 jun. 2007.

21. SILVA, José Augusto da. A arbitragem no processo de globalização. Disponível em: $<$ http://www.institutodeengenharia.org.br/cmaie/leiamais.html.>. Acesso em: $5 \mathrm{dez}$. 2006.

22.SÃO PAULO. CÂMARA DE ARBITRAGEM EMPRESARIAL - CAMARB. Disponível em: <http://www.camarb.com.br/principal/default.aspx >. Acesso em: 8 jun. 2007.

23. SÃO PAULO. ARBITRAL - CÂMARA DE ARBITRAGEM EMPRESARIAL DE SÃO PAULO. Disponível em: <http://www.sparbitral.com.br/clausula.htm>. Acesso em: 8 jun. 2007 